NBER WORKING PAPER SERIES

\title{
CO-WORKER COMPLEMENTARITY AND \\ THE STABILITY OF TOP MANAGEMENT TEAMS
}

\author{
Rachel M. Hayes \\ Paul Oyer \\ Scott Schaefer \\ Working Paper 10350 \\ http://www.nber.org/papers/w10350 \\ NATIONAL BUREAU OF ECONOMIC RESEARCH \\ 1050 Massachusetts Avenue \\ Cambridge, MA 02138 \\ March 2004
}

\begin{abstract}
We are grateful to the American Compensation Association's Emerging Scholars Program and the General Motors Center for Strategy Research at Kellogg for support. Thanks to Charles Himmelberg, Kevin Hallock, three referees and various seminar participants for comments, and to Kevin Hallock for generously sharing his data on layoff announcements by Fortune 500 firms. The views expressed herein are those of the authors and not necessarily those of the National Bureau of Economic Research.
\end{abstract}

C2004 by Rachel M. Hayes, Paul Oyer, and Scott Schaefer. All rights reserved. Short sections of text, not to exceed two paragraphs, may be quoted without explicit permission provided that full credit, including (C) notice, is given to the source. 
Co-Worker Complementarity and the Stability of Top Management Teams

Rachel M. Hayes, Paul Oyer, and Scott Schaefer

NBER Working Paper No. 10350

March 2004

JEL No. J44, J63, M50

\section{ABSTRACT}

We investigate the hypothesis that complementarities across co-workers (which may arise from matching or investments in specific skills) affect the value of employment relationships between senior executives and firms. We analyze the changes in the composition of top management teams when a key member of the team (the CEO) departs. Our empirical analysis establishes several facts that are consistent with co-worker complementarity being an important determinant of management team stability.

Rachel M. Hayes

Graduate School of Business

University of Chicago

rachel.hayes@gsb.uchicago.edu

Paul Oyer

Graduate School of Business

Stanford University

518 Memorial Way

Stanford, CA 94305-5015

and NBER

pauloyer@stanford.edu

Scott Schaefer

Kellogg School of Management

Northwestern University

s-schaefer@kellogg.northwestern.edu 


\section{Introduction}

People do not work in isolation. Most employees create value by combining their efforts and talents with other individuals at the same firm. Doing so is most valuable if individuals combine their skills with others who have complementary skills.

In this paper, we explore the implications of co-worker complementarity for work groups in firms. We first show that co-worker complementarity implies that when one of a complementary pair of employees leaves the firm, the probability the other leaves the firm increases as well. That is, complementarity implies contemporaneous association in employee turnover. We then show that the magnitude of this change in the probability of turnover depends on the strength of complementarities with the departing and incoming employees. Specifically, when one employee leaves, the resulting change in the probability that another employee leaves is increasing in the strength of the complementarity between them. Further, this change in probability is decreasing in the strength of the complementarity between the employee and the departing employee's replacement.

We examine these implications empirically using data on teams of top managers. Our analysis centers on relationships between firms' Chief Executive Officers (CEOs) and other members of top management teams. We begin by observing that the unconditional likelihood of non-CEO managerial turnover is 13.8 percent, but that this figure rises to 17.7 percent in years when there is contemporaneous CEO turnover, and to 24.4 percent when the incoming CEO has been employed by the firm for five years or less. ${ }^{1}$ In our empirical analysis, we assess whether this pattern is consistent with the hypothesis of co-worker complementarity.

Our main empirical strategy is to estimate a series of logit models that allow the probability a manager leaves the firm to depend on characteristics of the firm, the manager, and the firm's CEO. We present three main empirical findings. First, the probability of non-CEO turnover rises markedly around times of CEO turnover. Second, this increase in non-CEO turnover around times of CEO turnover - a quantity we refer to as the "CEO/manager turnover association" - is highest for managers whose tenure with the firm is similar to that of the

\footnotetext{
${ }^{1}$ Throughout the paper, we refer to employees who do not hold the position of Chief Executive Officer as "managers" and employees who do hold the Chief Executive Officer position as "CEOs." We reserve the term "executive" to refer to members of both groups.
} 
departing CEO. For example, long-tenured managers are more likely (compared to short-tenured managers) to depart the firm when a long-tenured CEO departs. Similarly, short-tenured managers are more likely (compared to long-tenured managers) to depart when a short-tenured CEO departs. Third, when an incoming CEO is relatively new to the firm, the CEO/manager turnover association is highest for long-tenured managers. We argue that these results are largely consistent with the idea of complementarities across individuals within top management teams.

Co-worker complementarity is not the only theory that can predict contemporaneous turnover among members of top management teams. Other candidate theories include learning models where corporate boards use correlated signals to update beliefs regarding executives' abilities, tournaments, and models where executives' skills complement a particular strategy or set of business practices. These are all potentially important, and we do not argue that co-worker complementarity is the only factor driving the $\mathrm{CEO} /$ manager turnover association. Rather, we argue that none of these theories can easily explain the empirical patterns unless one also allows for complementarities across co-workers. We discuss versions of the tournament, correlatedsignals learning, and strategy complementarity models that omit co-worker complementarities, and argue that these versions of the theories are not consistent with the data.

We highlight several potential contributions of this work. First, we believe our paper to be the first to quantify the effects of complementarities across specific individuals within firms. Numerous previous studies have documented the value of sharing information and working together. Gant, Ichniowski and Shaw (2002), for example, study the sharing of information across jobs within a production process, but do not consider whether the identities of specific employees within those jobs affect group productivity. Second, while there is a large body of work on the implications of firm-specific human capital, relatively little has been done to carefully identify the actual sources of firm-specific aspects of individual productivity. Our results suggest that some specificity may be derived from complementarities with the firm's other employees. Third, while the large literature on CEO turnover has documented significant links between firm performance and the likelihood of CEO departure (see Warner, Watts and Wruck (1988) and Barro and Barro (1990)) and between board composition and CEO departure (see Weisbach (1988)), research in this field has not, to date, carefully examined employment 
outcomes among a firm's top non-CEO managers. ${ }^{2}$ Finally, more recent work in corporate finance (see, for example, Weisbach (1995), Denis and Denis (1995), and Mulherin and Poulsen (1998)) shows that various forms of organizational changes are more common after changes in the CEO position. Our results suggest that managerial turnover is yet another dimension on which organizational changes are associated with CEO changes, and that implementation of organizational changes stemming from CEO turnover may require changes in the incumbent top management team.

The three studies most comparable to ours are Helmich and Brown (1972), Wruck and Wruck (2002) and Fee and Hadlock (2004). Helmich and Brown study 208 changes in the "President" position for evidence of associated turnover among other executives. They find an association between outside succession and turnover among other executives, but make no comparison between firms experiencing turnover in the President position and firms experiencing no turnover in this position. Wruck and Wruck (2002) study the formation of multiple groups of top managers from within a single firm after a part of that firm is spun off. They show that a top "line" manager from the part of the firm that is spun off is often teamed with a top "staff" manager from the rest of the firm. This suggests a complementarity across line and staff jobs within top management teams.

In a contemporaneous paper, Fee and Hadlock (2004) also show that managerial turnover is significantly higher near the time of CEO change. They interpret their results as consistent with both a "team-specific human capital" model and a model where signals of managerial performance are correlated. Our study (which makes use of a broader sample) leads us to conclude the correlated signals model is not an important driver of the relationship between CEO and managerial change. Our analysis also differs from theirs in that we examine the characteristics of managers who join and depart top management teams, and explore the interactions among those characteristics for evidence consistent with co-worker complementarity. Fee and Hadlock instead emphasize how departure from a top management team affects an executive's subsequent career. Thus, we view their paper as a study of labor market outcomes for non-CEO

\footnotetext{
${ }^{2}$ Most existing work on employment outcomes for non-CEO managers uses this form of turnover as simply a broader indicator of change at the top of the organization. See Furtado and Rozeff (1987), Warner et al. (1988), Kaplan (1994a), Kaplan (1994b), Denis and Denis (1995) and Mikkelson and Partch (1997).
} 
executives, and ours as an analysis of factors affecting the composition of productive groups within organizations.

Finally, we note that our analysis is similar in spirit to that found in the large literature on the dynamics of job changes in labor markets. There, matching and specific skill acquisition offer potential explanations for the fact that the probability of job change is inversely related to the employee's tenure with the firm. While the empirical patterns are largely consistent with this explanation, the literature has not, to date, offered convincing direct evidence in favor of these hypotheses (see Farber (1999)). Our analysis, which relies on matching or specific skill acquisition to predict a positive CEO/manager turnover association, suffers from a similar limitation. While we argue that the patterns in the data appear consistent with co-worker complementarity, the difficulty of directly measuring such complementarities precludes a sharper test.

The remainder of our paper proceeds as follows: In Section 2, we develop a simple model of co-worker complementarity and generate empirical implications. We describe our data and present our empirical analysis in Section 3. In Section 4, we discuss other theories that can predict a positive $\mathrm{CEO} /$ manager turnover association, and argue that these theories cannot explain the findings unless co-worker complementarity is also present. We conclude in Section 5.

\section{Co-Worker Complementarity and Turnover}

In this section, we use a stylized model to derive implications of co-worker complementarity for managerial turnover. Consider a firm that must employ two executives. Let $f$ be a function mapping the identities of the firm's executives to firm profits gross of wages $f: M \times M \rightarrow \mathbb{R}$. Suppose the firm faces competition in the labor market, and let the outside wage for executive $m_{i} \in M$ be denoted by $w_{i}^{\prime}$.

It is efficient for the firm to employ an executive if the surplus generated by this employment match exceeds that of any other employment match. Thus, conditional on employing executive $m_{1}$, it is efficient for the firm to employ executive $m_{2}$ if

$$
f\left(m_{1}, m_{2}\right)-w_{2}^{\prime}>f\left(m_{1}, m_{j}\right)-w_{j}^{\prime}
$$

for all $m_{j} \neq m_{1}, m_{2} \in M$. If, on the other hand, the firm does not employ executive $m_{1}$, then 
it is efficient for the firm to employ executive $m_{2}$ if

$$
f\left(m_{i}, m_{2}\right)-w_{2}^{\prime}>f\left(m_{i}, m_{j}\right)-w_{j}^{\prime}
$$

where $m_{i}$ is the next best alternative executive to $m_{1}$.

To derive an empirical model from these relations, let $w_{2}^{\prime}$ be a random variable with cumulative distribution function $G{ }^{3}$ Suppose further that the firm employs executives $m_{1}$ and $m_{2}$ in period $t$. Conditional on employing executive $m_{1}$ in period $t+1$, the probability of turnover from $t$ to $t+1$ for executive $m_{2}$ is given by

$$
1-G\left[f\left(m_{1}, m_{2}\right)-f\left(m_{1}, m_{j}\right)+w_{j}^{\prime}\right]
$$

In words, executive $m_{2}$ will leave the firm if the value of his outside opportunity increases sufficiently so that the period $t$ employment match is no longer efficient. ${ }^{4}$ If executive $m_{1}$ is not employed in period $t$, then the probability of turnover from $t$ to $t+1$ for executive $m_{2}$ is given by

$$
1-G\left[f\left(m_{i}, m_{2}\right)-f\left(m_{i}, m_{j}\right)+w_{j}^{\prime}\right] .
$$

Thus, the increase in the probability of executive $m_{2}$ departure when executive $m_{1}$ departs is

$$
G\left[f\left(m_{1}, m_{2}\right)-f\left(m_{1}, m_{j}\right)+w_{j}^{\prime}\right]-G\left[f\left(m_{i}, m_{2}\right)-f\left(m_{i}, m_{j}\right)+w_{j}^{\prime}\right]
$$

If executives $m_{1}$ and $m_{2}$ complement each other, then

$$
f\left(m_{1}, m_{2}\right)-f\left(m_{1}, m_{j}\right)>f\left(m_{i}, m_{2}\right)-f\left(m_{i}, m_{j}\right) .
$$

\footnotetext{
${ }^{3}$ Our model here can be enriched in a variety of ways without affecting the basic insights. We could, for example, treat all wages as random variables, add search costs, or model the informational asymmetries that may affect external hiring. Also, one can interpret $f$ more broadly as the sum of productivity and the value of on-the-job consumption. Complementarity, in the on-the-job consumption case, could stem from employees working with their friends, and the firm may be able to capture the benefits associated with this complementarity through reduced wages. Note that even if the firm cannot capture the benefits of such "cronyism," it is still the case that efficient employment matches will depend on the extent of this co-worker complementarity.

4 This outside opportunity can be interpreted as leisure rather than work. It is efficient for an employment relationship to end in a "retirement" when the value of the employee's leisure time is sufficiently high.
} 
Because $G$ is non-decreasing, it is straightforward to show that if $m_{1}$ and $m_{2}$ are complements, then the probability of executive 2's departure is (weakly) higher when executive 1 departs. The intuition for this result is this: Executive 2 should be employed by the firm if this employment match is efficient. If executive 1 departs, then the value created by executive 2 when employed by this firm falls because of the lost complementarity between the two executives. This increases the likelihood that the match between the firm and executive $m_{2}$ is no longer surplus-maximizing, and hence increases the likelihood of turnover.

The co-worker complementarity reflected in (2) may arise from a number of sources. Executives may simply be endowed with skills that are complemented by those of another executive. For example, an executive with operational skills may be well matched with another whose talents lie in setting strategic direction. Alternatively, executives may learn to work with each other over time, developing a stock of human capital that is specific to co-workers. ${ }^{5}$ As an illustration of these effects from the management literature, Vancil (1987) emphasizes the importance of "cohesion" among a top management team. As the team members "work together, discussion becomes more efficient, a common data base evolves, a shared jargon develops, and biases become clear. Managers who have been through many wars together can handle a heavy agenda because they need not waste a lot of time trying to understand each other" (p. 119).

Interpreting $m_{2}$ as a non-CEO manager and $m_{1}$ as a CEO, the quantity in (1) is exactly the "CEO/manager turnover association" we defined above. ${ }^{6}$ This construct is our main object of study in the empirical analysis below. The first hypothesis arising from our model of co-worker complementarity is therefore that the $\mathrm{CEO} /$ manager turnover association is positive.

We develop our second and third hypotheses by re-focusing on the inequality in (2). The left-hand side of this inequality is the increase in the firm's profit (gross of wages) when

\footnotetext{
${ }^{5}$ Parrino (1997) analyzes how career outcomes for top managers are affected by accumulation of specific human capital.

${ }^{6}$ Focusing on complementarities between CEOs and non-CEO managers seems natural given most firms' hierarchical reporting structures. While the relationship between the CEO and each individual non-CEO would seem to be important, it is less clear that each manager-to-manager relationship is important. Our reasoning, however, can apply equally well to any two employees of a firm. We do briefly examine manager-to-manager complementarity below — see Section 3.3.
} 
matching executive 2 rather than executive $j$ with executive 1 . Economically, it can be interpreted as the effect of executive 2's presence on executive 1's productivity; this term therefore represents the quality of the match between executive 2 and executive 1 . It is immediate that the $\mathrm{CEO} /$ manager turnover association (that is, expression (1)) is increasing in $f\left(m_{1}, m_{2}\right)-f\left(m_{1}, m_{j}\right)$. This comparative static leads to our second hypothesis: holding all else fixed, the $\mathrm{CEO} /$ manager turnover association should be greater when the complementarity between the manager and the departing CEO is stronger.

The right-hand side of the inequality in (2) is the increase in the firm's profit (gross of wages) when matching executive 2 rather than executive $j$ with executive $i$. It is the effect of executive 2 's presence on executive $i$ 's productivity, and represents the quality of the match between these two executives. The CEO/manager turnover association is decreasing in $f\left(m_{i}, m_{2}\right)-f\left(m_{i}, m_{j}\right)$, leading to our third hypothesis. Holding other factors constant, the CEO/manager turnover association should be smaller when the complementarity between the manager and the incoming CEO is stronger.

\section{Empirical Analysis}

\subsection{Data}

To conduct our empirical analysis, we augment the standard data source used in studies of top management compensation with a number of hand-collected data items. Compustat's ExecuComp is a panel data set consisting of detailed information on executive compensation for a broad cross-section of firms from 1994 to 2000. Throughout our sample period, publicly traded firms in the U.S. were required to disclose (in their proxy statements) the identity and pay of (1) all individuals serving as CEO for any part of the year, (2) the next four most highly paid executive employees if their pay exceeded $\$ 100,000$, and (3) up to two other individuals for whom disclosure would have been provided had the individual been an employee of the firm at the end of the fiscal year. Consequently, these disclosures provide a snapshot of the identities and pay levels of each firm's top executives at a given point in time. To facilitate inter-firm comparability, we select the executive listed by ExecuComp as CEO and the next four most highly paid executives, and refer to this set of executives as the firm's group of "proxy-named 
executives." 7

We augment this data by hand-collecting information regarding each executive's age and employment history from firms' annual reports. SEC rules require firms to identify executive officers and certain other "significant" employees annually. We refer to the list of executives and other significant employees disclosed in a given year as the firm's "executive officer group," and we note that SEC rules require the group of proxy-named executives to always be a subset of the executive officer group. For each employee in the executive officer group, we can observe whether that employee has been with the firm for at least five years and, if not, how long the employee has been with the firm. We define a variable "Tenure $<5$ years" to take value one if the executive has been an employee of the firm for less than five years, and zero otherwise. ${ }^{8}$

In addition to collecting age and experience information, we use the executive officer group to devise a measure of executive turnover. Constructing a turnover measure using only the list of proxy-named executives is problematic because of the pay-rank criteria for inclusion in the proxy. The criteria for inclusion in a firm's executive officer group are, however, unrelated to pay levels. ${ }^{9}$ While it is possible that an employee could be present in a firm's executive officer group in year $t$ and remain an employee of the firm but drop out of the executive officer group

${ }^{7}$ Unfortunately, ExecuComp makes a practice of "filling in" pay information for managers who did not appear in firms' proxy statements in a given year. If, for example, a manager appears in a firm's year $t$ proxy statement and the firm reports pay information retroactively for years $t-1$ and $t-2$, then this manager will often be included by ExecuComp in the list of year $t-1$ and $t-2$ managers for that firm. Using the entire ExecuComp sample (which includes these filled-in executives) would bias our results, because a manager can be filled in for year $t-1$ only if he or she does not leave the firm from year $t-1$ to $t$. Restricting attention to only the CEO and the four most highly paid managers omits these cases.

${ }^{8}$ In defining this variable, we take the length of time since the employee first became an employee of the firm. If, for example, an executive joined a firm as an employee is 1983, retired as an employee in 1994 but remained on the firm's board of directors, and then became an employee again in 1996, then we would record this employee's 1996 tenure as 13 years.

${ }^{9}$ The group of executive officers, as defined in Rule 405 of the Securities Act of 1933, refers to employees who are "in charge" of a unit, division or function, or perform a "policy making function." In our data, there are 6,149 cases where a manager leaves a firm's group of proxy-named executives. In 4,111 of these, the manager also left the firm's executive officer group. 
in year $t+1$, this can happen only if there is a substantial change in the functions performed by that employee. ${ }^{10}$ For each executive $i$ listed in firm $j$ 's year $t$ group of proxy-named executives, we define turnover as follows:

$$
\text { Non-CEO Manager Turnover } i t= \begin{cases}0 & \text { if executive } i \text { is listed in firm } j \text { 's } \\ & \text { year } t+1 \text { executive officer group } \\ 1 & \text { otherwise }\end{cases}
$$

We apply a different definition for CEO turnover, because an executive can leave the CEO position but still remain a member of the executive officer group. For each firm $j$ and year $t$, we define CEO turnover as follows: ${ }^{11}$

$$
\text { CEO Turnover }_{t}= \begin{cases}0 & \text { if the executive listed as firm } j \\ & \text { CEO at the end of year } t \text { is still } \\ & \text { listed as CEO at the end of year } t+1 \\ 1 & \text { otherwise }\end{cases}
$$

Our final sample consists of 8,122 firm-years and 37,906 executive-years. ${ }^{12}$ We present summary statistics for employee-level variables in Table 1 and for firm-level variables in Table 2. Notably, the raw data on managerial turnover appears to offer strong support for our first hypothesis. Table 1 reports that while the unconditional rate of non-CEO managerial turnover is 13.8 percent, this rate jumps by nearly a third, to 17.7 percent, in years where there is also CEO turnover. If the incoming $\mathrm{CEO}$ has been with the firm for less than five years, this rate

10 There are cases where a manager leaves the executive officer group but remains a non-employee director of the firm. We are not aware of any cases where a manager is present in the executive officer group in year $t$ and $t+2$, but not year $t+1$.

${ }^{11}$ Because ExecuComp occasionally lists a CEO who left during year $t$ as the year $t$ CEO, we hand checked each CEO departure to ensure we match the departure to the correct fiscal year.

${ }^{12}$ We were able to hand-collect complete age and employment history information for more than $96 \%$ of the executive-years in the original ExecuComp sample. Missing age and experience data are primarily due to missing annual reports on the SEC or 10kwizard web sites. Also, to limit the potential effect of outliers in our data, we drop the lowest and highest $1 \%$ of market and accounting returns. Inclusion of these firms in our analysis has no qualitative effect on our findings. We also drop firm-years where there is CEO turnover as a result of a merger or spinoff. 
jumps to 24.4 percent. We turn next to assessing this $\mathrm{CEO} /$ manager turnover association using regression analysis.

\subsection{The CEO/Manager Turnover Association}

We begin by documenting factors that are related to the probability of executive turnover. In Table 3, we present results from estimating a series of logit models where the dependent variable is a measure of executive turnover. In Column (1), we use our indicator for CEO turnover as the dependent variable. In Columns (2) through (4), we use non-CEO managerial turnover as the dependent variable.

We include characteristics of both the firm and the individual executive as independent variables. Firm-level variables include log assets, indicator variables for industry at the 2-digit SIC code level, year indicators, indicators for the number of employees in the firm's group of proxy-named executives, and measures of industry-adjusted firm-performance. To construct our measures of industry-adjusted firm performance, we begin with the firm's shareholder return and return on assets (which ExecuComp defines as net income before extraordinary items and discontinued operations divided by total assets) in year $t$. We adjust for industry effects by subtracting the mean stock return and ROA in that two-digit industry in that year, dropping industry-years for which we have fewer than five firms. ${ }^{13}$ We then construct indicator variables based on percentiles of industry-adjusted firm performance variables. For ease of presentation, we present regressions that include indicator variables for quintiles of industry-adjusted firm performance. $^{14}$

Executive-level variables include the fraction of the firm's common stock owned by the executive, indicators for the executive's rank (first through fifth) in salary and bonus compensation among the firm's group of proxy-named executives, an indicator for firm tenure less than five years, and indicators for age categories. We define four age categories: below 55, 55 to 63,64

${ }^{13}$ All results are robust to using medians, rather than means, in computing industry adjustments.

14 An alternative would be to include industry-adjusted stock return and return on assets linearly in our regression. Our approach estimates a more flexible relationship between firm performance and the likelihood of executive turnover. Our qualitative findings are invariant to this specification choice. Results are also robust to using deciles of firm performance. 
Table 1: Executive-Level Summary Statistics

\begin{tabular}{|c|c|c|}
\hline & CEOs & Non-CEO Managers \\
\hline Executive-years & 8,122 & 29,784 \\
\hline Annual Rate of Turnover & $10.3 \%$ & $13.8 \%$ \\
\hline Annual Rate of Turnover Conditional on & & $17.7 \%$ \\
\hline \multicolumn{3}{|l|}{ Contemporaneous CEO Turnover } \\
\hline Annual Rate of Turnover Conditional on & & $24.4 \%$ \\
\hline \multicolumn{3}{|l|}{ Incoming CEO Tenure $<5$ years } \\
\hline \multicolumn{3}{|l|}{ Age } \\
\hline Mean & 55.5 & 50.6 \\
\hline Median & 55 & 51 \\
\hline Standard deviation & 7.49 & 7.54 \\
\hline \multicolumn{3}{|l|}{ Tenure $<5$ years } \\
\hline Mean & 0.17 & 0.31 \\
\hline \multicolumn{3}{|l|}{ Salary + bonus } \\
\hline Mean $(\$ 000)$ & 1,180 & 554 \\
\hline Median $(\$ 000)$ & 850 & 405 \\
\hline Standard deviation & 1,797 & 630 \\
\hline \multicolumn{3}{|c|}{ Shares Owned as a Fraction of Total Shares Outstanding } \\
\hline Mean $(\%)$ & 3.15 & 0.43 \\
\hline Median (\%) & 0.40 & 0.04 \\
\hline Standard deviation & 6.97 & 2.13 \\
\hline
\end{tabular}

Table 2: Firm-level Summary Statistics

\begin{tabular}{lcccccc}
\hline \hline & Mean & Standard Deviation & Median & Minimum & Maximum & $\mathrm{N}$ \\
\hline Total assets (millions) & $\$ 8,550$ & $\$ 32,361$ & $\$ 1,253$ & $\$ 14$ & $\$ 717 \mathrm{~B}$ & 8,122 \\
Return on Assets (ROA - \%) & 4.85 & 6.79 & 4.62 & -40.00 & 24.00 & \\
Shareholder Return (RET - \%) & 18.1 & 43.5 & 12.2 & -65.9 & 250.0 \\
Size of proxy-named executive group & 4.88 & 0.44 & 5 & 2 & 5 & \\
\hline
\end{tabular}


Table 3: Determinants of Executive Turnover

\begin{tabular}{|c|c|c|c|c|}
\hline & CEO Turnover & Non- & EO Man & Turnover \\
\hline & $(1)$ & $(2)$ & $(3)$ & $(4)$ \\
\hline \multirow[t]{2}{*}{ Lowest ROA Quintile } & 0.036 & 0.027 & 0.024 & 0.019 \\
\hline & $(2.90)$ & $(5.08)$ & $(4.79)$ & $(3.07)$ \\
\hline \multirow[t]{2}{*}{ Lowest RET Quintile } & 0.065 & 0.023 & 0.020 & 0.019 \\
\hline & $(4.90)$ & $(4.69)$ & $(4.20)$ & $(3.26)$ \\
\hline \multirow[t]{2}{*}{ Age between 55 and 63} & 0.043 & 0.063 & 0.060 & 0.058 \\
\hline & $(7.67)$ & $(14.30)$ & $(14.04)$ & $(11.45)$ \\
\hline \multirow[t]{2}{*}{ Age between 64 and 66} & 0.268 & 0.282 & 0.272 & 0.217 \\
\hline & $(16.59)$ & $(17.21)$ & $(16.94)$ & $(12.81)$ \\
\hline \multirow[t]{2}{*}{ Age greater than 66} & 0.140 & 0.131 & 0.125 & 0.104 \\
\hline & $(10.13)$ & $(8.19)$ & $(7.95)$ & $(6.13)$ \\
\hline \multirow[t]{2}{*}{ Fraction Ownership } & -0.004 & -0.008 & -0.007 & -0.008 \\
\hline & $(4.83)$ & $(5.08)$ & $(5.01)$ & $(3.92)$ \\
\hline \multirow[t]{2}{*}{ CEO Tenure $<5$ years } & -0.004 & 0.043 & 0.041 & 0.031 \\
\hline & $(0.48)$ & $(7.40)$ & $(7.37)$ & $(4.75)$ \\
\hline \multirow[t]{2}{*}{ Manager Tenure $<5$ years } & & 0.023 & 0.023 & 0.035 \\
\hline & & $(5.60)$ & $(5.61)$ & $(5.90)$ \\
\hline \multirow[t]{2}{*}{ Manager Tenure $<5$ years*Age between 55 and 63} & & -0.052 & -0.050 & -0.060 \\
\hline & & $(4.46)$ & $(4.34)$ & $(3.63)$ \\
\hline \multirow[t]{2}{*}{ Manager Tenure $<5$ years*Age between 64 and 66} & & -0.036 & -0.042 & 0.015 \\
\hline & & $(0.53)$ & $(0.61)$ & $(0.15)$ \\
\hline \multirow[t]{2}{*}{ Manager Tenure $<5$ years*Age greater than 66} & & -0.139 & -0.138 & -0.110 \\
\hline & & $(2.52)$ & $(2.54)$ & $(1.29)$ \\
\hline \multirow[t]{2}{*}{ CEO Age between 55 and 63} & & -0.011 & -0.012 & -0.011 \\
\hline & & $(3.60)$ & $(3.92)$ & $(2.89)$ \\
\hline \multirow[t]{2}{*}{ CEO Age between 64 and 66} & & -0.028 & -0.032 & -0.023 \\
\hline & & $(4.30)$ & $(4.92)$ & $(2.90)$ \\
\hline \multirow[t]{2}{*}{ CEO Age greater than 66} & & -0.032 & -0.034 & -0.030 \\
\hline & & $(5.00)$ & $(5.45)$ & $(4.19)$ \\
\hline \multirow[t]{2}{*}{ Manager Tenure $<5$ years* CEO Tenure $<5$ years } & & -0.054 & -0.053 & -0.049 \\
\hline & & $(5.24)$ & $(5.28)$ & $(3.37)$ \\
\hline \multirow[t]{2}{*}{ CEO Turnover } & & & 0.046 & 0.048 \\
\hline & & & $(9.91)$ & $(10.04)$ \\
\hline $\mathrm{N}$ & 8,122 & 29,784 & 29,784 & 17,428 \\
\hline
\end{tabular}

Column 1 dependent variable is an indicator for whether CEO leaves the CEO position from year $t$ to year $t+1$. Columns 2 through 4 dependent variables are indicators for whether the manager leaves the firm's list of "Executive Officers" from year $t$ to year $t+1$. Parameters are probability derivatives. Robust asymptotic $t$-statistics, adjusted for within-firm correlation, in parentheses. Regressions include log assets, indicators for the executive's compensation rank, the number of executives listed in the firm's proxy statement, year, 2-digit SIC industry, and second, fourth and fifth quintiles of industry-adjusted firm performance. Columns 3 and 4 include indicators for whether the manager became CEO in year $t+1$. In Column 3 , CEO Turnover indicates contemporaneous CEO turnover, while in Column 4 it indicates contemporaneous or prior year turnover. 
to 66 , and over $66 .{ }^{15}$ Coefficients estimated by logit models are difficult to interpret economically, so we instead present the derivative of the probability of CEO turnover with respect to each independent variable. ${ }^{16}$ For indicator variables, we present the predicted change in the probability the dependent variable changes from zero to one as the indicator changes from zero to one.

From Column (1), we see that age and firm performance are associated with CEO turnover. The omitted categories for our firm-performance variables are the third (middle) quintiles; thus, the positive and significant coefficients on Lowest ROA Quintile and Lowest RET Quintile indicate that CEO turnover is more likely when the firm performs poorly relative to other firms in its industry. CEO turnover is 3.6 (6.5) percentage points more likely when the firm's return on assets (stock return) is in the lowest quintile as compared to the middle quintile. While we omit the coefficients on the remaining quintile indicators from the table, we find that firms in the second quintile of stock performance are more likely by 2.7 percentage points $(p$-value $=$ 0.02) to experience CEO turnover. The coefficients on none of the other performance variables are statistically different from zero. Our omitted age category is 54 and younger, so results indicate that CEOs become more likely to turn over as they get older. As many authors have found, CEOs are most likely to turn over when around the standard retirement age. CEOs who hold smaller percentage ownership stakes in their firms are also more likely to turn over. ${ }^{17}$

In Column (2), we run a similar specification for non-CEO managers, but add a number of independent variables that are not present in our CEO specification from Column (1). We

${ }^{15}$ We allow the ages 64 through 66 to be a separate category because many executives retire at around age 65 . We experimented with various ways of defining age categories, but found similar effects.

${ }^{16}$ Probability derivatives are calculated at the median executive and firm characteristics, and the modal year and SIC code. For example, median non-CEO age is 51 years, so we compute non-CEO probability derivatives (for variables other than the age category indicators) by setting indicators for the 55 to 63,64 to 66 , and over 66 categories to zero.

17 We also tried including the value of restricted stock and unexercisable options held by an executive. Coefficients on these variables were not statistically distinguishable from zero, and our other inferences were unaffected by their inclusion. While such grants are presumably made to increase the cost to employees of leaving the firm, their obvious endogeneity complicates the interpretation of these regression coefficients. 
add variables relating to the characteristics of the firm's CEO, including CEO age categories, a variable for whether the CEO's tenure with the firm is less than five years, and a CEO/manager tenure interaction.

We find these managers are more likely by 2.7 and 2.3 percentage points to turn over when firm performance drops from the third to the first quintiles of return on assets and stock return, respectively. The age category variables matter for these managers in much the same way they do for CEOs. Further, the probability of managerial turnover is significantly higher when the firm's CEO has been with the firm for less than five years. This effect, however, holds for only those managers who have been with the firm for more than five years. Specifically, a manager who has more than five years' tenure with the firm is 4.3 percentage points more likely to turn over when the firm's CEO has less than five years' tenure compared to when the firm's CEO has more than five years' tenure. However, the probability of turnover for a manager with less than five years' tenure with the firm is unrelated to the CEO's tenure with the firm. (That is, we cannot reject the hypothesis that the sum of the coefficients on Manager Tenure $<5$ years and Manager Tenure $<5$ years* CEO Tenure $<5$ years sum to zero.) Column (2) also shows the probability of managerial turnover to be higher when the firm's CEO is young, and that the relationship between managerial tenure and turnover probability varies markedly with age. The finding that the Manager Tenure $<5$ years*Age greater than 66 interaction is significantly negative may reflect that a firm and a manager past standard retirement age would be unlikely to enter into a new employment relationship if both sides did not have a reason to believe that the relationship would last for some amount of time. In unreported specifications, we found this effect is not present for the CEO turnover regression in Column (1) of Table 3.

In Column (3), we add the CEO Turnover variable. The coefficient on this variable is the increase in the probability of managerial turnover when there is CEO turnover, compared to the case of no CEO turnover. It is therefore the ceteris paribus calculation of the CEO/manager turnover association we defined in Section 2. ${ }^{18}$ We find that CEO turnover from year $t$ to year

\footnotetext{
18 We also add an indicator for whether the manager takes over as CEO. This indicator predicts the dependent variable (remaining in the executive officer group) perfectly, so inclusion of this variable has the effect of dropping those executive-years where the manager becomes the firm's CEO the following year. Hence, the correct interpretation of the coefficient on CEO Turnover is the following: conditional on the manager not being selected as the new CEO, how much does the likelihood of turnover increase when there is CEO
} 
$t+1$ is associated with an increase of 4.6 percentage points in the likelihood of managerial turnover. This coefficient estimate is significantly different from zero at better than the one percent level. The unconditional likelihood of managerial turnover is 13.8 percent, so CEO turnover is associated with an increase by one-third in the likelihood of managerial turnover. We conclude that the contemporaneous $\mathrm{CEO} /$ manager turnover association is both economically and statistically significant. ${ }^{19}$

Finally, in Column (4) we broaden our definition of CEO Turnover to take value 1 if the firm experienced CEO turnover from year $t-1$ to $t$ or from year $t$ to year $t+1$. In this regression, we also drop all managers who were new to the firm in year $t$. The coefficient on CEO Turnover therefore reflects the increase in the likelihood of year $t$ to $t+1$ managerial turnover when there was contemporaneous or prior year CEO turnover, conditional on the manager having been in the group of proxy-named executives at the start of the prior year. The coefficient on CEO Turnover is positive and significant at far better than the one percent level. Our estimates suggest that CEO turnover in the contemporaneous or prior year increases the likelihood of managerial turnover by 4.8 percentage points. We also estimated more flexible specifications that allow contemporaneous and prior-year CEO turnover to have different effects on managerial turnover. We were unable to reject the hypothesis that the effects of contemporaneous and prior-year CEO turnover are the same. These two effects do differ significantly from the effect of year $t-2$ to $t-1$ CEO turnover (as we found in unreported specifications). It appears, therefore, that the effect of CEO turnover on the likelihood of non-CEO managerial turnover persists for a period of around two years.

We conclude that Columns (3) and (4) of Table 3 offer strong support for our first hypothesis from Section 2 - that the CEO/manager turnover association is positive. Here, we find that this association is positive, appears to have a duration of about two years, and is both statistically

turnover?

19 This, and all our main results, are robust to a number of alternative specifications. In an earlier version of this paper, we took the firm (rather than the individual non-CEO manager) as the unit of analysis and estimated a series of ordered logit models where the dependent variable was the number of non-CEO managers who turned over in a given year. Also, we estimated a model with firm fixed-effects (see Chamberlain (1980)) to verify that our results are not driven by firm-level heterogeneity in rates of managerial turnover. 
and economically significant.

\subsection{Effects of CEO and Manager Characteristics}

Next, we explore our second and third hypotheses; namely, that the CEO/manager turnover association is related to the extent of complementarities present between executives. To do this, we rely extensively on our measures of executive tenure with the firm. Our reasoning here runs parallel to that used in the literature on job changes. Models of matching of workers to firms with uncertain ex ante match quality (see Jovanovich (1979b)) and accumulation of firmspecific human capital (Parsons (1972) and Jovanovich (1979a)) both predict that worker/firm complementarity should be increasing in tenure, and thus that the probability of job change should be decreasing in tenure. Here, we reason that uncertain ex ante co-worker match quality or accumulation of co-worker specific skills can lead to the same effect. That is, co-worker complementarity should be increasing in the amount of time employees have worked together. Hence, to examine our second and third hypotheses, we look at how the CEO/manager turnover association varies with tenure of the departing $\mathrm{CEO}$, the incoming $\mathrm{CEO}$ and the manager.

We begin by asking whether the $\mathrm{CEO} /$ manager turnover association is related to characteristics of the departing and incoming CEOs. In Column (1) of Table 4, we interact an indicator for contemporaneous CEO turnover with our tenure indicator for departing CEOs. ${ }^{20}$ The point estimate on the interaction is small, and is not statistically distinguishable from zero. While CEO turnover leads to a substantial increase in the likelihood of managerial departure, the magnitude of this effect does not - in this specification - appear to be related to the tenure of the departing CEO.

The tenure of the incoming $\mathrm{CEO}$ is, on the other hand, related to the $\mathrm{CEO} /$ manager turnover association. As the Column (2) regression shows, managers are 5.3 percentage points more likely to turn over when the incoming CEO has been with the firm five years or less compared to when the incoming CEO has been with the firm for more than five years. This effect is significant at better than the one percent level. The $\mathrm{CEO} /$ manager turnover association is not driven entirely by short-tenured incoming CEOs, however. The CEO Turnover indicator remains significant

${ }^{20}$ We also experimented with interacting CEO Turnover with categories for the ages of the departing and incoming CEOs, but could find no pattern. 
as well, with the probability derivative implying that succession of a CEO with greater than five years tenure means a 2.4 percentage point increase in the likelihood of managerial turnover.

In Column (3), we further explore how the $\mathrm{CEO} /$ manager turnover association is related to characteristics of the incoming CEO. Specifically, we place incoming CEOs into one of four categories:

1. Incoming $\mathrm{CEO}$ was an employee of the firm in year $t$ with tenure greater than five years. (538 events)

2. Incoming CEO was an employee of the firm in year $t$ with tenure less than five years. (169 events)

3. Incoming $\mathrm{CEO}$ was a director but not an employee of the firm in year $t$. (43 events)

4. Incoming CEO was not an employee or director of the firm in year $t$. (164 events)

We create indicator variables "Short-Tenured Employee," "Non-Employee Director," and "External Hire" for the second through fourth categories, respectively, and interact these indicators with our CEO Turnover variable. ${ }^{21}$

Our estimates suggest that the probability of managerial turnover is higher by 7.0 percentage points when the new $\mathrm{CEO}$ was hired from outside the firm compared to the case where the new CEO is a long-tenured insider. This difference is significant at better than the one percent level. Managerial turnover probabilities are higher by 4.4 and 4.6 percentage points, respectively, when the new $\mathrm{CEO}$ is a short-tenured insider and a director. These estimates are significant at better than the one and two percent levels. While we can reject the hypothesis that the coefficients on CEO Turnover*External Hire, CEO Turnover*Non-Employee Director, and CEO Turnover*Short-Tenured Employee are all zero, we cannot reject the hypothesis that the three coefficients are identical.

${ }^{21}$ Recall from footnote 8 that our tenure variable is defined with respect to the first date an individual became an employee of the firm. Hence, nearly half of the 43 instances where non-employee directors take over as CEO are cases where Incoming CEO Tenure $<5$ years $=0$, as these are cases where board members who are former employees take over as CEO. We tried partitioning our Non-Employee Director indicator on whether the director was a former employee or not, but gained no additional insight. 
Table 4: Departing and Incoming CEO Characteristics

\begin{tabular}{|c|c|c|c|c|c|c|}
\hline & \multicolumn{3}{|c|}{$\begin{array}{l}\text { Contemporaneous } \\
\text { CEO Turnover }\end{array}$} & \multicolumn{3}{|c|}{$\begin{array}{c}\text { Contemporaneous and Prior } \\
\text { Year CEO Turnover }\end{array}$} \\
\hline & (1) & $(2)$ & $(3)$ & (4) & $(5)$ & (6) \\
\hline CEO Turnover & $\begin{array}{l}0.064 \\
(7.94)\end{array}$ & $\begin{array}{l}0.024 \\
(3.80)\end{array}$ & $\begin{array}{l}0.021 \\
(3.28)\end{array}$ & $\begin{array}{l}0.047 \\
(8.14)\end{array}$ & $\begin{array}{l}0.051 \\
(5.65)\end{array}$ & $\begin{array}{l}0.030 \\
(5.52)\end{array}$ \\
\hline CEO Turnover* Departing CEO Tenure $<5$ years & $\begin{array}{l}0.008 \\
(0.35)\end{array}$ & & & $\begin{array}{l}0.042 \\
(2.37)\end{array}$ & & \\
\hline CEO Turnover* Incoming CEO Tenure $<5$ years & & $\begin{array}{l}0.053 \\
(4.57)\end{array}$ & & & $\begin{array}{l}0.051 \\
(4.39)\end{array}$ & \\
\hline CEO Turnover* Short-Tenured Employee & & & $\begin{array}{l}0.044 \\
(4.97)\end{array}$ & & & $\begin{array}{l}0.031 \\
(2.23)\end{array}$ \\
\hline CEO Turnover* Non-Employee Director & & & $\begin{array}{l}0.046 \\
(2.36)\end{array}$ & & & $\begin{array}{l}0.011 \\
(0.48)\end{array}$ \\
\hline CEO Turnover* External Hire & & & $\begin{array}{l}0.070 \\
(2.90)\end{array}$ & & & $\begin{array}{l}0.075 \\
(5.04)\end{array}$ \\
\hline $\mathrm{N}$ & 29,784 & 29,784 & 29,784 & 17,428 & 17,428 & 17,428 \\
\hline
\end{tabular}

Dependent variables are indicators for whether non-CEO manager leaves the firm's list of "Executive Officers" from year $t$ to year $t+1$. Reported parameters are probability derivatives. Robust asymptotic $t$-statistics, adjusted for within-firm correlation, in parentheses. Firm-level variables included in each regression are log assets, CEO age, and indicators for quintiles of industry adjusted stock-market and accounting returns, 2-digit SIC indicators, year, number of individuals in group of proxy-named executives, and year $t$ CEO tenure. Executive level-variables are fraction ownership, compensation rank, age categories, indicators for tenure less than five years and whether the manager became the next CEO, and age/tenure, manager tenure/CEO tenure interactions. 
In Columns (4) through (6), we extend our indicator variables for CEO turnover to allow for contemporaneous and prior year turnover. ${ }^{22}$ Inferences here are similar to those obtained from Columns (1) through (3), with two exceptions. First, we do find an effect of departing CEO tenure on managerial turnover. Departure of a short-tenured CEO in the current or prior year is associated with a 4.2 percentage point increase in the likelihood of managerial turnover. Second, if the incoming $\mathrm{CEO}$ is a non-employee director, then managerial turnover is not significantly higher compared to when the new CEO is a long-tenured insider. Combined with the result from Column (3), this finding suggests that when a non-employee director takes over as CEO starting in year $t$, year $t$ to $t+1$ managerial turnover is lower than in the case where there is no contemporaneous or prior year CEO turnover. Our more flexible specifications (unreported) confirm this finding.

To summarize, the main result arising from Table 4 is that managerial turnover is significantly higher when the incoming CEO has shorter tenure with the firm. This offers some indirect support for our third hypothesis. When the match between the incoming CEO and the manager is weaker (as captured by the incoming CEO having spent little time working at the firm), the CEO/manager turnover association is larger.

Our hypotheses can be more directly examined, however, by looking at the interactions between executive characteristics. In Column (1) of Table 5, we interact our non-CEO manager tenure and departing CEO tenure indicators with our CEO turnover indicator. We also include the triple interaction among the three indicators. This specification allows us to determine whether the length of overlap between manager and departing CEO work histories is related to the probability of managerial turnover.

To interpret this regression, note that the coefficient on the CEO Turnover indicator estimates the $\mathrm{CEO} /$ manager turnover association for the omitted categories of a long-tenured manager and a long-tenured incoming CEO. The sum of the coefficients on CEO Turnover and the CEO Turnover*Manager Tenure $<5$ years interaction is the CEO/manager turnover association for the case of a short-tenured non-CEO manager and a long-tenured departing CEO. The sum of the CEO Turnover and the CEO Turnover*Departing CEO Tenure $<5$ years co-

${ }^{22}$ In cases where there was CEO turnover in both years, we use the characteristics of the contemporaneous departing and incoming $\mathrm{CEO}$ to define the interaction variables. 
Table 5: Interactions Among Executives' Characteristics

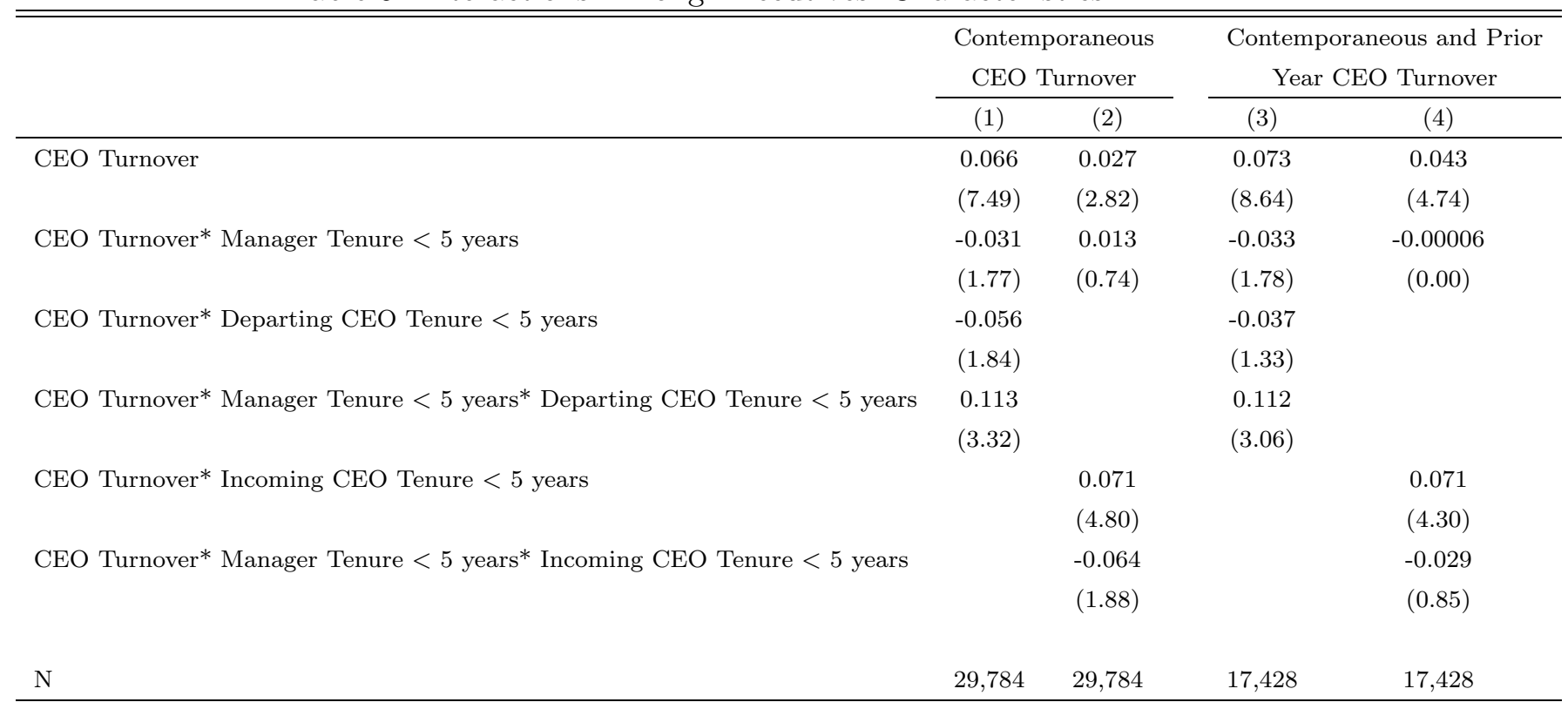

Dependent variables are indicators for whether manager leaves the firm's Executive Officer group from year $t$ to year $t+1$.

Reported parameters are probability derivatives. Robust asymptotic $t$-statistics, adjusted for within-firm correlation, in parentheses. Firm-level variables included in each regression are log assets, CEO age, and indicators for quintiles of industry adjusted stock-market and accounting returns, 2-digit SIC indicators, year, number of individuals in group of proxy-named executives, and year $t$ CEO tenure. Executive level-variables are fraction ownership, compensation rank, age categories, an indicator for tenure less than five years, and age/tenure, manager tenure/CEO tenure interactions. 
efficients is the $\mathrm{CEO} /$ manager turnover association for the case of a long-tenured non-CEO manager and a short-tenured departing CEO, while the sum of the four coefficients (including the triple interaction) is the association when both executives are short-tenured.

These probabilities are easier to compare when displayed in a two-by-two matrix, as in Panel A of Figure 1. Rows correspond to different levels of non-CEO manager tenure, while columns correspond to different levels of departing CEO tenure. In each cell, we enter the estimated $\mathrm{CEO} /$ manager turnover association for that manager-tenure/departing-CEO-tenure pair. To illustrate, the number in the lower-right cell (0.066) is our point estimate of the increase in the probability of long-tenured manager turnover when a long-tenured CEO departs compared to when there is no CEO turnover. The number in the lower-left cell (0.010) is the CEO/manager turnover association for the case of a long-tenured non-CEO manager and a short-tenured departing CEO. Arrows between adjacent cells indicate that the turnover probabilities in the connected cells are statistically different from each other, with $p$-value listed in parentheses.

Panel A of Figure 1 offers strong support for our second hypothesis. Note specifically that the on-diagonal cells (those for which the CEO and non-CEO executives' firm tenures are the same) are highest in magnitude, and are significantly different from the magnitudes in the offdiagonal cells. If a CEO and a manager have both been with the firm for five years, then CEO departure is associated with an increase in the likelihood of manager departure of 6.6 percentage points. If the departing CEO has been with the firm for less than five years, then the increase in managerial turnover probability is only 1.0 percentage point. This is significantly different from the case where both are long-tenured at better than the $7 \%$ level. If, on the other hand, the manager has been with the firm for less than five years but the departing CEO has been with the firm for more than five years, the increase in managerial turnover probability is just 3.5 percentage points. This is significantly different from the case where both are long-tenured at better than the $6 \%$ level.

The most striking result from the matrix is the very high $\mathrm{CEO} /$ manager turnover association for the case where both managers are short-tenured. This association is significantly larger than that for the case where only one is short-tenured at better than the $1 \%$ level. Within our framework, one could construct either a matching or a specific-capital explanation for this finding. One possibility is that short-tenured CEOs hire additional managers from outside only 
if they have strong reason to believe that those outsiders are good matches with themselves. Alternatively, it may be the case that the short-tenured departing CEO and the short-tenured manager accumulated specific skills by working together at another firm prior to joining the present employer. We present some evidence on this second explanation in Section 3.4 below.

To recap our main finding from Panel A of Figure 1, it appears that the match between the tenures of the manager and the departing CEO plays an important role in determining how CEO turnover is related to turnover of other managers. This result is consistent with our hypothesis that the $\mathrm{CEO} /$ manager turnover association should be larger when the complementarity between the two executives is stronger. Recall also that in Column (1) of Table 4, we found that the tenure of the departing $\mathrm{CEO}$ was unrelated to the $\mathrm{CEO} /$ manager turnover association. The specification estimated there did not allow this effect to vary with the tenure of the manager, and hence misses the true effect.

We now consider our third hypothesis, which predicts that the CEO/manager turnover association will be small when the incoming CEO/manager complementarity is strong. Recall that Table 4 shows that the $\mathrm{CEO} /$ manager turnover association is strongly related to the tenure of the incoming CEO. We now explore whether this relationship varies with the tenure of the manager. Our third hypothesis has three implications for this analysis. First, we expect the smallest CEO/manager turnover association when both the incoming CEO and the manager are long-tenured. Second, we expect the CEO/manager turnover association to be larger for long-tenured manager/short-tenured incoming CEO combinations than for short-tenured manager/short-tenured incoming CEO combinations. Finally, conditional on the incoming CEO having long tenure, we expect a higher CEO/manager turnover association for shorttenured managers than for long-tenured managers. We test these implications in Column (2) of Table 5 by including a set of interaction variables relating to the tenures of the manager and the incoming CEO. However, as with the Table 5 Column (1) regression, it is easier to interpret our estimates by referring to a two-by-two matrix.

As Panel B of Figure 1 indicates, the empirical patterns are consistent with all three of these implications (although the third is not statistically significant). The CEO/manager turnover association is smallest when the manager and the incoming CEO both have short tenures. Further, while long-tenured managers are only moderately (2.7 percentage points) more likely 
to turn over when there is an incoming long-tenured CEO, they are substantially more likely to turn over (9.8 percentage points) when there is an incoming short-tenured CEO. This difference is significant at far better than the one percent level. Our finding from Table 4 - that non-CEO managers are more likely to depart the firm when the incoming CEO is relatively new to the firm - appears to be driven by departure of managers who have been with the firm for more than five years. Finally, while we do find that short-tenured managers are more likely to turn over (by 4.0 percentage points) when there is a long-tenured incoming CEO, this magnitude is not significantly larger than that for long-tenured managers (2.7 percentage points).

In Columns (3) and (4) of Table 5, we repeat this analysis using contemporaneous and prioryear CEO turnover. A similar pattern, with somewhat lesser statistical significance, is observed. Specifically, we again find that match between tenures of a manager and a departing CEO is important. Also, new incoming CEOs appear to affect turnover probabilities for long-tenured managers only.

We ran additional specifications combining the explanatory variables in Columns (1) and (2) of Table 4, and including the four way interaction between CEO Turnover, Manager Tenure $<5$ years, Departing CEO Tenure $<5$ years, and Incoming CEO Tenure $<5$ years. This allows the construction of a three-dimensional analogue to the matrices in Figure 1, where the three dimensions are non-CEO manager tenure, departing CEO tenure, and incoming CEO tenure. Estimation of this model confirms that both effects identified above - that (1) the $\mathrm{CEO} /$ manager turnover association is greatest when the manager and departing CEO have matching tenures, and (2) short-tenured incoming CEOs increase departure probabilities for long-tenured managers - are present in the data when controlling for the other.

Finally, we note our reasoning from Section 2 can be applied not just to CEO/manager relationships, but also to manager/manager pairs. To examine our main hypotheses in the manager/manager context, we dropped all managers holding the title "President," "Chief Operating Officer," or "Chief Financial Officer" from our sample of non-CEO managers. We then constructed an indicator variable for high-ranking managerial turnover, where a manager is considered to be of high rank if he holds one of the three positions listed above. Using specifications similar to Column (3) of Table 3, we found that high-ranking managerial turnover is significantly associated with low-ranking managerial turnover, even when restricting the sample 
Figure 1: Number in each cell is the estimated CEO/manager turnover association. Arrows indicate that the difference between the two estimates is statistically significant, with $p$-values in parentheses. Panel A and B associations can be computed directly from the regressions in Columns (1) and (2), respectively, of Table 5 .

Panel A: CEO/Manager Turnover Association as a Function of Manager and Departing CEO Tenure (From Table 5, Column 1)

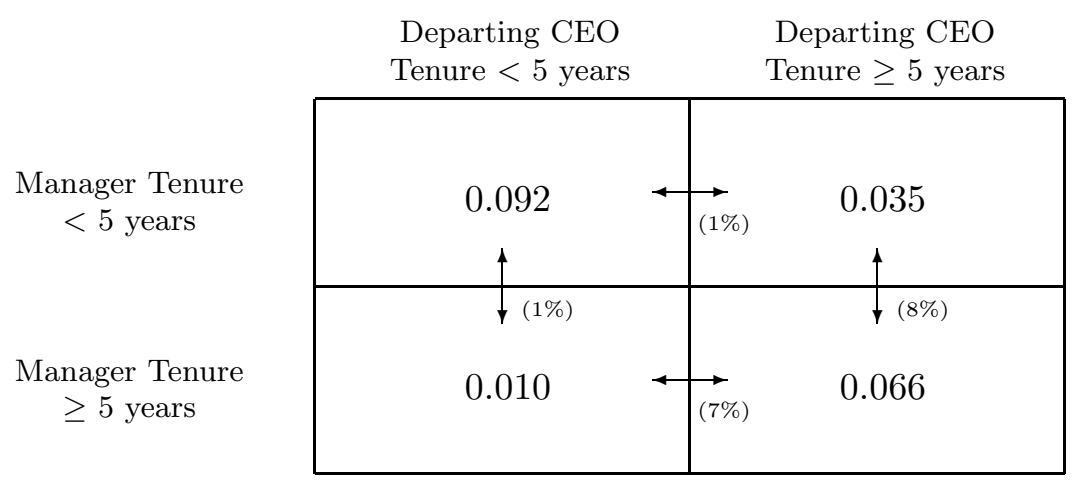

Panel B: CEO/Manager Turnover Association as a Function of Manager and Incoming CEO Tenure (From Table 5, Column 2)

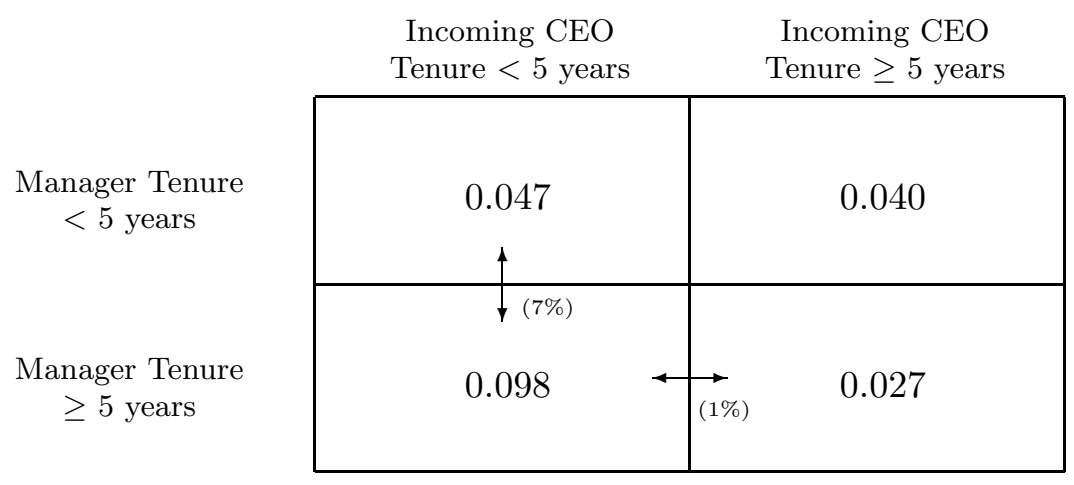


to firm-years where there is no CEO turnover. Further, we find a similar pattern to that in Panel A of Figure 1 with regard to tenure matches between high- and low-ranking non-CEO managers, albeit without statistical significance.

We conclude that the evidence in this subsection supports our second and third hypotheses. Departing CEO tenure does have a substantial impact on the probability of managerial departure, but this effect differs according to whether the manager in question has an employment history that overlaps with the departing CEO. Further, succession of a short-tenured CEO does affect the probability of managerial departure, but only for long-tenured managers.

\subsection{Incoming Non-CEO Managers}

Next, we briefly examine the characteristics of incoming non-CEO managers. Our objective here is to look for evidence of complementarity between CEOs and managers who are new to the firm. As we discussed above, one potential explanation for our Figure 1 Panel A result is that short-tenured CEOs and short-tenured managers accumulated specific skills by working together at another firm prior to joining the present employer.

To do this, we look at the characteristics of managers who enter a firm's group of proxynamed executives. Specifically, we examine the likelihood a manager who joins the proxy group has been with the firm for less than five years; that is, we study the "short/join probability," defined as

Prob[manager is short-tenured | manager joins group of proxy-named executives].

In our data, there are 4,711 cases where a manager makes his first appearance in a firm's group of proxy-named executives. ${ }^{23}$ Of these, $54.5 \%$ have tenure at their firm of less than five years. Therefore, the short/join probability over our entire sample is $54.5 \%$.

Given our co-worker complementarity hypothesis, we would expect the short/join probability to be high when a short-tenured manager becomes CEO. Similarly, when a long-tenured

${ }^{23}$ One source of bias in our measure is that we do not observe groups of proxy-named executives for years prior to 1994. Hence, a manager who is in the group of proxy-named executives in 1993 and again in 1995 will be treated by our measure as being new to the group of proxy-named executives in 1995. As a robustness check, we re-defined our measure of "joining" to include any manager who is present in a group of proxy-named executives in year $t$ but not year $t-1$. This had little effect on our findings. 
manager is promoted to CEO, we would expect newcomers to the top management group to be likely to come from inside the firm (that is, we expect a low short/join probability.) Both of these patterns are found in the data.

We first examine how the short/join probability is affected by CEO turnover. We find that, if there was CEO turnover from year $t$ to year $t+1$, then managers who join the firm's group of proxy-named executives in year $t+1$ are actually less likely to be short-tenured. Of the 701 managers who joined their firms' proxies in the year after CEO turnover, 346 (49.4\%) had tenure less than five years. A chi-squared test rejects the hypothesis (at better than the 1\% level) that the short/join probability is the same when there is CEO turnover compared to when there is no turnover.

When the incoming CEO is relatively new to the firm, however, the short/join probability is higher. Our sample contains 253 managers who join their firm's proxy-named executive groups in the year after a short-tenured executive becomes CEO; of these, 149 (58.9\%) had been with the firm for less than five years. On the other hand, we have 448 managers who join the proxynamed executive groups in the year after a long-tenured executive becomes CEO; of these, only $197(44.0 \%)$ had been with the firm for less than five years. We can reject the hypothesis that the short/join probability is the same after short- and long-tenured CEO succession at better than the $1 \%$ level. $^{24}$

These findings raise the following question: To what extent do new CEOs bring non-CEO managers with them from prior places of employment? That is, do top management teams tend to move en masse from one firm to another? To answer this question, we revisit firms' proxy statements and annual reports and collect information (where available) regarding the prior place of employment for all short-tenured CEOs in our sample. We collect the same information for short-tenured managers who join the firms' groups of proxy-named executives under these CEOs.

We find little evidence that short-tenured CEOs bring managers from their prior places of employment. Of the 510 short-tenured, new-to-proxy managers who are paired with short-

${ }^{24}$ We observe a similar pattern with respect to departing CEOs, but lose statistical significance. Specifically, the short/join probability is $48.7 \%$ when a long-tenured CEO departs, but $56.5 \%$ when a short-tenured CEO departs. The $p$-value from a chi-squared test is 0.138 . 
tenured CEOs, we are able to locate prior-employer information for both the manager and the CEO in 445 cases. In only $43(9.7 \%)$ of these cases did the manager and the CEO share the same prior employer. ${ }^{25}$ Thus, it appears that while new CEOs are disproportionately likely to hire managers from outside the firm, these managers are quite unlikely to have the same prior place of employment as the CEO. This result suggests that accumulation of specific human capital at a prior place of employment does not play a significant role in explaining our results from Panel $\mathrm{A}$ of Figure 1. If the large $\mathrm{CEO} /$ manager turnover association for the case of a short-tenured departing CEO and a short-tenured manager reflects co-worker complementarity, then it is likely attributable to effective matching in the managerial labor market as opposed to specific skill acquisition.

\section{Other Theories of Associated Turnover for Top Executives}

As we discussed in the introduction, co-worker complementarity is not the only theory that can predict contemporaneous turnover among members of top management teams. Other candidates include learning models where corporate boards use correlated signals to update beliefs regarding executives' abilities, tournaments, and models where executives' skills complement a particular strategy or set of business practices. In this section, we discuss each candidate theory in turn. We first sketch how the theory can generate a positive CEO/manager turnover association. We then discuss any additional implications of each theory, and report our attempts to evaluate these implications using our data.

\subsection{Learning}

CEO and managerial turnover may be associated if boards of directors use positively correlated signals to update beliefs regarding these executives' abilities. Hermalin and Weisbach (1998),

25 This number reflects 39 unique firms, as there are four cases where two managers follow a CEO from one firm to another. As an example, recall 1996 appointment of Gil Amelio as CEO of Apple Computer. Amelio had previously been employed as CEO of National Semiconductor, and managers George Scalise and Ellen Hancock entered Apple's group of proxy-named executives from National Semiconductor under Amelio. Notably, three other managers entered Apple's group of proxy-named executives under Amelio: one each from IBM, Texas Instruments and ADP. 
for example, consider a setting where a board and a CEO are symmetrically uninformed regarding the CEO's ability at the time of hiring. The board uses any information it receives to make inferences regarding ability, and fires the CEO if its belief about the executive's ability falls below some critical level at which the board prefers to hire the best alternative CEO. A straightforward extension of such a model would allow boards to make simultaneous inferences regarding the abilities of both $\mathrm{CEO}$ and non-CEO managers. If the signals used to make inferences regarding these managers are positively correlated (as would be the case if firm performance is used to assess both), then the board's assessment of the ability of non-CEO managers is likely to be low relative to the next alternative manager around times of CEO turnover.

While learning models have many implications, one important prediction here is that the association between CEO and managerial turnover should depend on firm performance. Because it is unlikely that learning is behind CEO turnovers that are accompanied by good firm performance, the likelihood of managerial turnover should be lower around such events. ${ }^{26}$ To examine this issue, we interact CEO Turnover with industry-adjusted firm-performance variables. We can then test the joint hypothesis that the CEO Turnover/firm-performance-indicator interactions are non-zero. We estimated a number of such models, but in none of them could we reject the hypothesis that the CEO/manager turnover association is unrelated to firm performance. For example, we estimated the model in Columns (3) and (4) of Table 3 including interactions between CEO Turnover and our firm performance indicators. In these regressions, none of the coefficients on the performance/CEO turnover interactions are individually significant, and we cannot reject the hypothesis that all are zero. In addition, we cannot reject the hypothesis that the coefficients on the interactions between CEO turnover and just the two lowest performance quintiles are zero. This result suggests that the learning hypothesis does not, by itself, appear to offer a strong justification for the positive CEO/manager turnover association.

\footnotetext{
${ }^{26}$ Note, however, that good firm performance should lead to increases in the estimated ability of all executives, which could result in improved outside options for all executives. If CEOs and managers are all more likely to be hired away when firm performance is good, then turnover can be associated with good firm performance. In our logit model, this effect would manifest itself as a higher $\mathrm{CEO} /$ manager turnover association when firm performance is in the highest quintile. We expect few such events are present in our data, because CEO-to-CEO job movements are rare.
} 
This conclusion stands in contrast to Fee and Hadlock (2004). They conclude, on the basis of the fact that the $\mathrm{CEO} /$ manager turnover association is positive, that "this evidence appears consistent with managers being evaluated, in part, as a group." They also argue that this same result is consistent with "team-specific human capital." However, they make no attempt to distinguish between these ideas. In addition, although they never discuss the implications of this analysis for the learning hypothesis, they do find that the CEO/manager turnover association is quite similar whether or not the firm's performance is bad leading up to CEO turnover (see their Table 6). We believe the correlated signals hypothesis does not survive closer inspection of the $\mathrm{CEO} /$ manager turnover association in this paper or in Fee and Hadlock (2004).

\subsection{Tournaments}

Following Lazear and Rosen (1981), a large literature studies the role of promotion tournaments in providing effort incentives in firms. Managers who narrowly miss out on being selected as the next CEO do occasionally depart the firm, as some recent high-profile examples attest. If this effect is common, then the $\mathrm{CEO} /$ manager turnover association could reflect the decisions of tournament losers to leave.

We argue, however, that it is not obvious that tournament theory predicts a positive $\mathrm{CEO} /$ manager turnover association in the absence of co-worker complementarity. Specifically, there is nothing in the theory that requires the "loser" of the tournament to be employed by a different firm subsequent to the resolution of tournament uncertainty. If the loser's skills are more highly valued at the original employer than elsewhere in the economy (as one might expect if firm-specific human capital is present), then it is efficient for the loser to remain with the original employer.

In order for tournament theory to explain the $\mathrm{CEO} /$ manager turnover association in the absence of co-worker complementarity, one must answer the question of why it is efficient for tournament losers to depart the firm. We argue there are at least two potential ways of answering this question. First, the CEO job is unique in that firms typically need exactly one such employee, and that an employee's marginal product in this job is higher than in any other job in the firm. Hence, it is imaginable that a tournament loser's marginal product could be 
higher as a CEO of another firm than as a manager for his original employer. This would then cause tournament losers to be bid away by other employers. Second, the presence of a qualified successor (in the person of the tournament loser) may undermine the productivity of the newly selected CEO. ${ }^{27}$

We emphasize two implications of this theory. First, tournament theory suggests that the increase in the likelihood of managerial departure around times of CEO turnover should be larger for those managers who are participants in the promotion tournament. This would lead us to expect the $\mathrm{CEO} /$ manager turnover association should be larger for executives who are not close to retirement age, as these are presumably the managers who are competitors in the promotion tournament. Second, in the absence of some form of co-worker complementarity, tournament models do not by themselves suggest a link between the CEO/manager turnover association and the characteristics of the departing or incoming CEOs. ${ }^{28}$

Neither implication fits strongly with our findings. While Table 3 does show that managerial turnover is more likely when the firm's CEO is young, we could not find any evidence that managerial age is related to the increase in the likelihood of turnover around times of CEO turnover. We experimented with a number of specifications where we interacted age, both linearly and with a variety of formulations of age categories, with CEO Turnover, but could find no relationship. Similarly, Table 4 and Figure 1 contradict the second implication.

We therefore conclude that, in the absence of some form of co-worker complementarity, tour-

27 The 2001 CEO succession tournament at General Electric provide an example of both phenomena. After Jeffrey Immelt was named the tournament winner, Bob Nardelli and James McNerney were quickly hired as CEOs of Home Depot and 3M, respectively, at salaries comparable to that earned by Immelt at GE. It seems unlikely these managers could have been as valuable to GE as non-CEO managers as they were to their new employers as CEO. GE fired both Nardelli and McNerney at the time Immelt was promoted. Explaining this decision, departing CEO Jack Welch (2001) wrote of his successor, "I don't want him looking over his shoulder."

${ }^{28}$ While selection of an outsider as CEO may make managers worse off if it indicates an increased willingness on the part of the firm to hire from outside, this does not by itself imply that outside CEO succession should have a greater effect on managerial turnover than inside CEO succession in the absence of co-worker complementarity. If it is efficient to retain managers after naming an outsider to the CEO job, the firm can renegotiate compensation contracts with these managers in order to do so. 
nament theory cannot by itself fully explain the empirical patterns in CEO/manager turnover associations. This does not, of course, imply that our findings are inconsistent with tournament theory. Related work by Hermalin and Weisbach (1988) finds that insiders are disproportionately likely to be added to corporate boards just before CEO turnover, and disproportionately likely to leave just after. They intrepret this as consistent with tournament theory, as boards promote insiders prior to a CEO change in order to learn about the contenders, and then demote (or fire) all but the winner. Their finding that CEO turnover is associated with departure of incumbent managers from the board is also consistent with co-worker complementarity. One point of differentiation between the studies is that we examine career outcomes for all non-CEO managers, not just those who are likely contenders for the CEO job. Tournament effects may be less prevalent in our sample as a result.

\subsection{Skills that Complement Strategy}

CEO and managerial turnover may be associated if executives invest in or possess skills that complement the firm's strategy or business practices. Under this hypothesis, a firm that seeks to change its strategy will place a reduced value on its incumbent managers. The key implication of this hypothesis is that the $\mathrm{CEO} /$ manager turnover association should be stronger when there are subsequent changes to the firm's strategy or business practices.

To examine this assertion, we estimated a number of models in which we allowed the $\mathrm{CEO} /$ manager turnover association to vary with indicator variables for subsequent reductions in assets or employment. Research on organizational changes following CEO turnover has shown that $\mathrm{CEO}$ turnover is associated with subsequent asset sales and employment reductions. We also obtained data on Fortune 500 firms' (a subset of our main sample) layoff announcements, and asked whether the pattern of top management turnover was related to these events. ${ }^{29}$ We could not find any evidence supporting the proposition that the CEO/manager turnover association is related to subsequent changes in strategy. We also note that while asset sales and layoffs are somewhat rough measures of changes in firms' strategies, we could also find no relation between the $\mathrm{CEO} /$ manager turnover association and firm performance. If firms are more likely to change their strategy when they perform badly, then this hypothesis would lead one

\footnotetext{
${ }^{29}$ Our layoff data is that studied by Hallock (1998) and Billger and Hallock (2000).
} 
to expect poor firm performance to lead to a stronger CEO/manager turnover association.

\section{Conclusion}

In this paper, we have presented an empirical analysis with three main findings. First, the probability of non-CEO managerial turnover is higher around times of CEO turnover. Second, the $\mathrm{CEO} /$ manager turnover association is highest for managers whose tenure with the firm is similar to that of the departing CEO. Third, when an incoming CEO is relatively new to the firm, the $\mathrm{CEO} /$ manager turnover association is highest for long-tenured managers.

We interpret our results as supporting the hypothesis of co-worker complementarity. Such complementarities could arise either through matching or through investment in specific skills. While it is difficult make sharp distinctions among these two hypotheses, the limited evidence available does point to the importance of matching in managerial labor markets. Relying solely on the specific investment hypothesis, it is difficult to explain our findings that (1) shorttenured non-CEO managers are substantially more likely to depart when short-tenured CEOs leave, and (2) incoming non-CEO managers are unlikely to have worked previously with new CEOs. Specific investment could underlie some of our other results, however.

Because our analysis has focused on turnover, we cannot isolate who captures the value of co-worker complementarity. These complementarities clearly lead to quasi-rents, and thus

raise the possibility that either firms or employees could capture the associated benefits. A different empirical design would be necessary to determine the exact extent to which firms benefit from higher managerial productivity and to what extent managers capture the benefits through cronyism. 


\section{References}

Barro, J. R. and Barro, R. J.: 1990, Pay, performance, and turnover of bank CEOs, Journal of Labor Economics 8, 448-481.

Billger, S. and Hallock, K.: 2000, Mass layoffs and management turnover. Working Paper, University of Illinois.

Chamberlain, G.: 1980, Analysis of covariance with qualitative data, Review of Economic Studies 47, 225-238.

Denis, D. J. and Denis, D. K.: 1995, Performance changes following top management dismissals, Journal of Finance 50, 1029-1057.

Farber, H. S.: 1999, Mobility and stability: The dynamics of job change in labor markets, in O. Ashenfelter and D. Card (eds), Handbook of Labor Economics, Vol. 3, North-Holland, Amsterdam.

Fee, C. E. and Hadlock, C. J.: 2004, Management turnover across the corporate hierarchy, Journal of Accounting and Economics p. Forthcoming.

Furtado, E. P. H. and Rozeff, M. S.: 1987, The wealth effects of company initiated management changes, Journal of Financial Economics 18, 147-160.

Gant, J., Ichniowski, C. and Shaw, K.: 2002, Working smarter by working together: Connective capital in the workplace. Working Paper, Carnegie Mellon University.

Hallock, K.: 1998, Layoffs, top executive pay, and firm performance, American Economic Review 85, 711-723.

Helmich, D. L. and Brown, W. B.: 1972, Successor type and organizational change in the corporate enterprise, Administrative Science Quarterly 17, 371-381.

Hermalin, B. E. and Weisbach, M. S.: 1988, The determinants of board composition, RAND Journal of Economics 29, 589-606.

Hermalin, B. E. and Weisbach, M. S.: 1998, Endogenously chosen boards of directors and their monitoring of the CEO, American Economic Review 88, 96-118.

Jovanovich, B.: 1979a, Firm specific capital and turnover, Journal of Political Economy 87, 1246-1260.

Jovanovich, B.: 1979b, Job matching and the theory of turnover, Journal of Political Economy 87, 972990.

Kaplan, S. N.: 1994a, Top executive rewards and firm performance: A comparison of Japan and the United States, Journal of Political Economy 102, 510-546. 
Kaplan, S. N.: 1994b, Top executives, turnover, and firm performance in Germany, Journal of Law, Economics and Organization 10, 142-159.

Lazear, E. P. and Rosen, S.: 1981, Rank-order tournaments as optimum labor contracts, Journal of Political Economy 89, 841-864.

Mikkelson, W. H. and Partch, M. M.: 1997, The decline of takeovers and disciplinary managerial turnover, Journal of Financial Economics 44, 205-228.

Mulherin, J. H. and Poulsen, A. B.: 1998, Proxy contests and corporate change: Implications for shareholder wealth, Journal of Financial Economics 47, 279-313.

Parrino, R.: 1997, CEO turnover and outside succession: A cross-sectional analysis, Journal of Financial Economics 46, 165-197.

Parsons, D. O.: 1972, Specific human capital: An application to quit rates and layoff rates, Journal of Political Economy 80, 1120-1143.

Vancil, R. F.: 1987, Passing the Baton: Managing the Process of CEO Succession, Harvard Business School Press, Boston.

Warner, J. B., Watts, R. L. and Wruck, K. H.: 1988, Stock prices and top management changes, Journal of Financial Economics 20, 461-492.

Weisbach, M. S.: 1988, Outside directors and CEO turnover, Journal of Financial Economics 20, 431460.

Weisbach, M. S.: 1995, CEO turnover and the firm's investment decision, Journal of Financial Economics 37, 159-188.

Welch, J.: 2001, Jack: Straight from the gut, Warner Books, New York.

Wruck, E. G. and Wruck, K. H.: 2002, Restructuring top management: Evidence from corporate spinoffs, Journal of Labor Economics 20, S176-S218. 